\title{
REGULAR ISSUE
}





\title{
THE TAXATION OF THE SO-CALLED DIRECT SALES IN THE POLISH PERSONAL INCOME TAX IN COMPARATIVE PERSPECTIVE ${ }^{1}$
}

\author{
Marcin Burzec*, Michalina Duda-Hyz**
}

\begin{abstract}
Article presents the principles for the taxation of the so-called direct sales of agricultural products on the basis of the personal income tax. The first part of the article includes remarks concerning the regulations introduced into the Polish legal system by way of the revision of the Pesonal Income Tax Law of April 2015. The second part of the article presents the principles of the so-called direct sales in France and Italy.
\end{abstract}

Key words: tax, personal income tax, direct sales of agricultural products

\section{INTRODUCTORY REMARKS}

Due to the problems related to the development of modern-age diseases, in highly-developed countries attention is increasingly being paid to the production and consumption of healthy food, produced in a tra-

${ }^{1}$ The article is based on the legislation in force on 1 September 2016. This article was written under a grant no. 2013/09/B/HS5/04503 financed by the National Science Centre.

* PhD - Associate Professor, Department of Finance and Finance Law, Faculty of Law, Canon Law and Administration, The John Paul II Catholic University of Lublin.

** PhD - Associate Professor, Department of Finance and Finance Law, Faculty of Law, Canon Law and Administration, The John Paul II Catholic University of Lublin. 
ditional way. When implementing the assumptions of social policy in the field public health, public authorities use, on the one hand, negative legal and financial stimuli, such as separate taxes or tax increases concerning highly-processed food or sweetened beverages ${ }^{2}$. On the other hand, public authorities use different tax preferences intended to encourage the production and consumption of products which are considered healthy. In the Polish tax system there are no separate taxes on the consumption of selected food products. The effect of taxation on shaping consumers' choices with regard to such products is also rarely discussed in the public debate and is usually limited to the taxation of alcoholic beverages and tobacco products. In this context, attention should be drawn to the revision, in April 2015, of the provisions regulating personal income tax, whose basic aim was to legally sanction the sales of low-processed, traditionally produced food, by farmers. The revision contains solutions which can be seen not only as an incentive for farmers to leave the informal sector but also to popularise food products which are not industrially processed. The changes introduced by the revision in question are noteworthy also because the production of food using traditional methods is for many farms a chance to improve their economic situation.

An undeniable result of an increase in social awareness of health-promoting behaviours is, among other things, an increased interest in food products which are perceived as healthy and ecological ${ }^{3}$. Such form of

2 The relevant literature mentions that the so-called fat taxes have become an element of health policies of states aiming to reduce the obesity epidemic. Countries which introduced such taxes include Denmark (tax on saturated fat), France („soda tax” on sweetened beverages) and Hungary (tax on foods with high fat, sugar and salt content), however Denmark lifted the tax in 2012 On the role and effectiveness of the so-called fat taxes. For more see e.g.,.: Andrew Leicester, Frank Windmeijer, The 'Fat Tax': Economic incentives to reduce obesity, „The Institute for Fiscal Studies. Briefing Note” 2004, no. 49, pp. 1-20; James Strnad, Conceptualizing the "fat tax": the role of food taxes in developed economies, "Southern California Law Review” 2005, vol. 78, pp. 1224-1322; Oliver Mytton, Alastair Gray, Mike Rayer, Harry Rutter, Could targeted food taxes improve health?, „Journal of Epidemiology and Community Health" 2007, vol. 61, pp. 689-694; David Madden, The poverty effects of a "Fat-Tax" in Ireland, Working Paper Series, UCD, Centre for Economic Research, No 13/03, http://hdl.handle.net/10419/72195 [retrieved: 20 March 2016].

${ }^{3}$ A study conducted by the Public Opinion Research Centre show in recent years are increasingly interested in all types of different diets; there are also more people who choose 
activity is becoming increasingly popular among farmers, as demonstrated by joint initiatives of direct sales from the farmer to the consumer, such as Paczka od Rolnika [A Parcel from a Farmer] or activities undertaken by the Polish Direct Selling Association ${ }^{4}$. The range and scope od direct sales, understood as direct selling of agricultural products produced on a farm to an end receiver, is also a subject of economic research. ${ }^{5}$. This research shows, inter alia, that although direct sales has been used as a distribution channel of agricultural products for a long time, its range is limited, which is mainly a result of hygiene and sanitary requirements ${ }^{6}$. In this context, one should also draw attention to the fact that, on the normative ground, the phrase "direct sales" was defined in the regulation of the European Parliament and the Council laying down specific hygiene rules on the hygiene of foodstuffs of animal origin ${ }^{7}$, referred to by the Act on Products of Animal Origin ${ }^{8}$. Although the provisions of tax law do not use this phrase, it should be emphasised that the scope of goods whose sales, as of 1 January 2016, is subject to preferential personal income tax treatment is wider than the "direct sales" within the meaning of the above mentioned hygiene and sanitary regulations - it also includes products of plant origin.

products marked as healthy and ecological when they do their shopping. See: Diety Polaków. Komunikat z badań CBOS, No. 113/2014, Warszawa, August 2014, http://www.cbos. pl/SPISKOM.POL/2014/K_113_14.PDF, Zachowania żywieniowe Polaków. Komunikat $z$ badań CBOS, No. 115/2014, Warszawa, August 2014, http://www.cbos.pl/SPISKOM. POL/2014/K_115_14.PDF, retrieved on: 17.11.2016.

${ }^{4}$ See: A. Sieczko, Sprzedaż bezpośrednia produktów żywnościowych z gospodarstw rolnych, Stowarzyszenie Ekonomistów Rolnictwa i Agrobiznesu. Roczniki Naukowe, vol. XVII (5), pp. 248-250. Information on the Polish Direct Selling Association is available on http://pssb.pl/pssb/rules/index,kodeks-etyczny.html, retrieved on: 17.11.2016.

${ }^{5}$ See: A. Borowska, Wsparcie instytucjonalne sprzedaży bezpośredniej produktów rolnych w Polsce $w$ latach 2007-2013 na przyktadzie targowisk, „Marketing i Rynek” 2015, no. 8, pp. 61-69.

${ }^{6}$ See: A. Kapała, J. Kalinowski, S. Minta, Sprzedaż bezpośrednia w Polsce na przyktadzie produktów pochodzenia zwierzęcego, Stowarzyszenie Ekonomistów Rolnictwa i Agrobiznesu. Roczniki Naukowe, vol. XVII (4), pp. 116-121.

${ }^{7}$ Regulation (EC) No. 853/2004 of 29 April 2004 laying down specific hygiene rules on the hygiene of foodstuffs of animal origin (Official Journal of the European Communities UE. L.2004.139.55, as amended)

${ }^{8}$ Article 5 (1) of the Act of 16 December 2015 on Products of Animal Origin (uniform text: Journal of Laws of 2014, item 1577, as amended) 
The primary aim of this article is to present the principles for the taxation of the so-called direct sales of agricultural products on the basis of the personal income tax against the solutions in this field in selected European Union states. The first part of the article includes remarks concerning the regulations introduced into the Polish legal system by way of the revision of the Personal Income Tax Law of April 2015. The second part of the article presents the principles of the so-called direct sales in France and Italy.

\section{THE TAXATION OF REVENUE FROM THE SO-CALLED DIRECT SALES}

OF FARMERS IN THE POLISH PERSONAL INCOME TAX

According to the provisions of the Personal income Tax Law which were in force until the end of 2015 farmers were allowed to produce and sell, without the necessity to pay the income tax, only unprocessed plant and animal products, such as fruit, vegetables, herbs, mushroom, eggs, honey and poultry'. The production and sales of processed food, e.g. jam, powidl or processed vegetables constituted economic activity to which the provisions of the Act of Freedom of Economic Activity were applicable ${ }^{10}$. Revenue from such, often very small-scale, activity was subject to taxation, as revenue from non-agricultural economic activity, which involved inter alia a duty to pay income tax advances and a duty to keep tax books. The only exception concerned the sales of brined products originating from farmer's own cultivation, which were subject to objective tax exemption ${ }^{11}$.

${ }^{9}$ Article 2 of the Act of 26 July 1991 on Personal Income Tax (Journal of Laws of 2016, item 2032, as amended.), hereinafter referred to as the Personal Income Tax.

${ }^{10}$ The provisions of the Act on Freedom of Economic Activity of 2 July 2004 (Journal of Laws of 2016, item 1829, as amended ) in wording in force until the end of 2015 were only not applicable to agricultural production in the field of growing crops, husbandry, gardening, vegetable-growing, forestry and inland fishing.

This exclusion did not therefore concern the activity of processing products produced by farmers. See the sentence of the Voivodeship Administrative Court in Warsaw of 25 May 2006, file no. VI SA/Wa 255/06, SIP Lex no. 276749.

${ }^{11}$ Article 21.1 (71) of the Personal Income Tax Act. 
As a result, the sale of products produced and processed on one's own farm was not profitable for many farmers and the demand for traditionally produced food was mainly met in the grey market.

On 9 April 2015 the Sejm passed a law on amending the Personal Income Tax Act and certain other laws ${ }^{12}$, which introduced significant changes in the taxation of income from the sales of processed agricultural products. It should be noted that the structure of the preference introduced by way of the amendment in question was considerably different from the proposal in the original version of the draft. According to the justification to the draft submitted by the Senate of the Republic of Poland, the aim of the amendment was "allowing farmers tax-free and deformalised production and sales of processed agricultural products ... on a small scale ${ }^{13}$.

Significantly, the Senate also noted the effect of improving the procedures for food production and improving its quality ${ }^{14}$.

The original version of the draft provided for the extension of the inventory of subjective exemptions to revenue from the sales of processed plant and animal products up to the amount not exceeding PLN 7000 in a calendar year, providing that the relevant records are kept. The activity of farmers in the field of selling to consumers processed plant or animal products originating from their farms was also to be excluded from material scope of the Act on Freedom of Economic Activity, and the excess revenue over PLN 7000 was to be subject to taxation as revenue from the so-called other sources. However, this qualification was not intended to include processed plant and animal products obtained within special sections of agricultural production and products covered by the excise tax. In addition, limiting the group of purchasers to consumers was also a condition for classifying revenue from the sales of processed products as the so-called revenue from other sources ${ }^{15}$.

${ }^{12}$ The Law of 9 April 2015 on Amending the Personal Income Tax Act and certain other laws (Journal of Laws, item 699).

${ }^{13}$ See the justification to the Senate draft of the Law on Ammending the Personal Income Tax Act and the Act on the Freedom of Economic Activity, Sejm Document No. 1640, the Sejm of the 7th term, p.1, www.sejm.gov.pl.

${ }^{14}$ Ibidem.

${ }^{15}$ In the opinion of some members of the Sejm such solution did not deserve support because it excluded a possibility to apply the drafted preference to the farmers who would 
As a result of adopting the amendments proposed the legislative work in the Sejm, a tax preference with a completely different legal structure was created. The essence of the solution currently in force consists in the inclusion of revenue from farmers' so-called direct sales into revenue from other sources within the law on the Personal Income Tax and also in introducing the possibility to tax it in a simplified form, i.e. by lump sum tax on registered income. Therefore, as of 1 January 2016, revenue from other sources includes revenue from the sales of plant and animal products, processed in a non-industrial way, originating from farmers' own cultivation, rearing or farming, except for processed plant and animal products obtained with the special sections of agricultural production and products subject to the excise $\operatorname{tax}^{16}$.

It is worth adding that in order to enable farmers to sell their own baked products, e.g. bread, a provision was added to the Law, laying out that flour made from grain originating from framers' own cultivation is also considered to be a plant product originating from farmers' own cultivation ${ }^{17}$. Revenue from this source is therefore not subject to taxation according to rules provided for revenue from economic activity. It should also be noted that the Law provides for a number of conditions that must be met so that revenue from the so-called direct sales may be taxed as revenue from other sources.

The first condition applies to purchasers, who may only be consumers. Such qualification shall not therefore cover the sales to legal persons, organisational units without legal personality or the sales to natural persons for the purposes of their non-agricultural economic activity.

The second condition is related to the persons who may take part in the process of processing plant and animal products and their sales. According the adopted regulation these activities may not involve persons employed under contracts of employment, mandate contracts (umowa zlecenia), con-

like to sell their products to e.g. restaurants or shops. See the typescript of the 48th Sitting of the Sejm of The Republic of Poland on 12 September 2013, p. 258, 261 and 163, http:// orka2.sejm.gov.pl/StenoInter7.nsf/0/6817B4C3C19BA553C1257BE50000BEAB/\%-

24File/48 b ksiazka.pdf [retrieved: 20 March 2016].

${ }^{16}$ Article 20 (1c) of the Personal Income Tax Act.

${ }^{17}$ Article 20 (1d) of the Personal Income Tax Act. 
tracts for specific work (umowa o dzieto) or other contracts of similar nature ${ }^{18}$. This restriction may be justified by the fact that the preference in question is aimed at farmers who produce and sell their products on their own or with a help of their family members or members of the household. The third and the most controversial condition applies to places where the products in question may be sold. The Law provides that only revenue from the sales in the places where given products were made and the sales in markets may be qualified as revenue from other sources. Therefore, revenue from sales conducted by the side of a road or from premises belonging to a farmer's family member may not take advantage of the preference in question.

It should also be noted that according to the legal definition, markets are any places intended for conducting trade, except for sales conducted in buildings or their parts ${ }^{19}$. Revenue from the sales of processed agricultural products in market halls and other places not designated for trade shall therefore be treated as revenue from non-agricultural economic activity. The last condition applies to the duty to keep the relevant sales records. Taxpayers conducting the so-called direct sales are obliged to keep, separately for each tax year, the records of the sales of plant and animal products containing at least: the number of each entry, the date of generating revenue, the revenue amount, and the cumulated revenue from the beginning of the year. In addition, daily revenue should recorded on the sales date ${ }^{20}$. The Law also provides that the records should be kept at the place where the processed plant and animal products are sold. It also follows form the wording of the provision in question that the taxpayer is obliged to keep one register which de facto means that it is not possible to sell simultaneously in a market and at the place where the products were made ${ }^{21}$.

${ }^{18}$ Article 20 (1c.3.c ) of the Personal Income Tax Act.

${ }^{19}$ Article 20 (1c.3.c) of the Personal Income Tax Act.. The definition of market under the Personal Income Tax Act is therefore different from the definition in the Local Taxes and Charges Act, in which it does not matter if the place where trade is conducted was designated for this purpose Article 15 (2) of the Local Taxes and Charges Act of 12 January 1991 r. (uniform text: Journal of Laws of 2014, item 849, as amended.).

${ }^{20}$ Article 20 (1e) of the Personal Income Tax Ac.

${ }^{21}$ Such opinion was also expressed by a representative of the Ministry of Finance during a debate on the analysed Law. See the typescript of the 73th sitting of the Senate 
According to the current regulations, in the case of profits/revenue from certain sources, taxpayers have the right to choose one of simplified forms of taxation. For revenue from economic activity, such forms are lump sum tax on registered revenue and a tax card ${ }^{22}$. As of 1 January 2016, taxation in the form of lump sum tax payment may also be used by farmers generating revenue from the direct sales mentioned above, providing that the amount of this revenue does not exceed the limit specified in the $\mathrm{Law}^{23}$. In such a case the tax rate is $2 \%$ of the revenue, which means it the lowest rate applied for the lump sum tax on recorded revenue ${ }^{24}$. In addition, farmers conducting the so-called direct sales are not obliged to keep the equipment records $s^{25}$.

Due to the fact that the lump sum tax on registered revenue is not a lump sum tax, i.e. the tax basis is still determined, it seems fully justified to impose on farmers a duty to keep simplified revenue records although such proposal was very controversial at the stage of the work on the amendment draft. Farmers generating revenue from the so-called direct sales are therefore obliged to keep, separately for each tax year, the records of the sales of plant and animal products containing at least: the number of each entry, the date of generating revenue, the revenue amount, and the cumulated revenue from the beginning of the year ${ }^{26}$.

The Law also provides that a farmer should keep the records in question at the place where processed plant and animal products are sold ${ }^{27}$,

of the Republic of Poland on 15 and 16 April 2015, p. 36, http://www.senat.gov.pl/prace/ senat/posiedzenia/przebieg,416,1,wersja-pdf.html [retrieved:: 21 March 2015].

${ }^{22}$ The Act of 20 November 1998 on Lump Sum Income Tax on Certain Revenues Earned by Natural Persons. (Journal of Laws No 144, item 930, as amended), hereinafter referred to as Lump Sum Tax Act.

${ }^{23}$ Article 6 ( $1 \mathrm{~d}$ and 4 ) of Lump Sum Tax Act. Revenue taxed in such a from is mutually incompatible with revenue/income from other sources subject to taxation on the basis of the Personal Income Tax Act.

${ }^{24}$ Article 12 (1. 6) of Lump Sum Tax Act.

${ }^{25}$ As a general rule, taxpayers settling the personal income tax in the form of lump sum tax on recorded revenue are obliged to maintain records of the equipment comprising tangible assets connected with the conducted non-agricultural economic activity not classified as fixed assets whose initial value exceeds PLN 1500.

${ }^{26}$ Article 15 (8) of Lump Sum Tax Act.

${ }^{27}$ Article 15 (9) of Lump Sum Tax Act. 
which means that it is not possible to sell products simultaneously in two different places. Just like other taxpayers who pay lump sum tax on recorded revenue, farmers conducting the so-called direct sales may deduct loss, within the meaning of the Income Tax Act, from their revenue and take advantage of the so-called relief from the profit if they will not be deducted from the profit or included the tax-deducible revenue on the basis of the Income Tax Act.

Proper recording of revenue is essential not only because of the necessity to determine the tax basis but also because of revenue limit over which one loses the right to use the lump sum tax on recorded revenue. In connection of the above, the amendment provides for a tax sanction which is applied if the duty to keep the relevant records is breached. If a tax authority concludes that a taxpayer does not keep the records of the sales of plant and animal products or keeps them contrary to the conditions required to consider them income in tax proceedings, the tax authority shall determine the amount of unrecorded revenue, also in the form of evaluation, and shall determine the tax on this amount as five times the $2 \%$ rate, i.e. $10 \%{ }^{28}$.

In conclusion, one should also highlight the issue of the loss of the right to benefit from the preference constituted by a possibility to pay lump sum tax on recorded revenue. According to the current regulations, if the conditions to pay lump sum tax on recorded revenue cease to exist, the tax payer is obliged, starting from the day when they cease to exist, to start keeping the relevant books - unless he or she is discharged from this duty - and pay income tax in accordance with the general conditions. In addition, in the case of farmers selling agricultural products made by them, breaching, within a tax year, the conditions provided for the so-called direct sales is also considered to be the loss of the conditions for benefitting from the simplified form of taxation ${ }^{29}$. It should be emphasised that in the case in which a taxpayer simultaneously conducts non-agricultural economic activity (sole trading), the loss of conditions also applies to revenue from this activity.

\footnotetext{
${ }^{28}$ Article 17 (3) of Lump Sum Tax Act.

29 Article 22 (3) of Lump Sum Tax Act.
} 


\section{THE TAXATION OF DIRECT SALES. \\ THE CASE STUDY OF FRANCE AND ITALY}

The tax treatment of the sales of processed agricultural products conducted by farmers is largely determined by the appropriate definition of the concept of agricultural activity. If we assume that the concept of agricultural activity covers the production of unprocessed plant and animal products, then any activities going beyond the activities specified in Law shall mean that selling products processed by a farmer, even if they originate from his or her own rearing or cultivation, is not recognised as agricultural activity. As a result, entities producing such products shall not eligible to a more preferential tax treatment, which is usually possible in the case of agricultural activity. If certain taxpayer's activities are not qualified as agricultural activity, usually means that such activities should usually be subject to the same tax treatment as economic activity. It should be emphasised that in the vast majority of European Union states, despite the fact that agricultural activity is subject to income tax, the fiscal burden of entities conducting such activity is usually lower than in the case of entities conducting economic activity. Such situation is a result of more preferential determination of the elements of the income tax structure that significantly affect the level of tax burden.

Such elements undoubtedly include the way of shaping the tax basis or the application of additional tax preferences taking into account the special character of agricultural productions. It should be noted the vast majority of European Union States the tax basis for entities conducting agricultural activity is fixed as a flat rate ${ }^{30}$. Nevertheless, even the states which do not fix the tax basis that would more beneficial for taxpayers apply tax preferences in the form of higher tax-free amount (as is the case in Portugal ${ }^{31}$ ) or in the form of possibility to average revenue from agricultural activity over

${ }^{30}$ Such situation usually takes place in the case of small and medium farms, in countries such as Germany, France, Italy, Spain and the Czech Republic.

${ }^{31}$ See article 3(4) of Codigo do Imposto sobre o Rendimento das Pessoas Singulares. 
a period of several years (Great Britain ${ }^{32}$ ). In certain states, such as Italy or France, the concept of agricultural activity goes slightly beyond ordinary production of plant and animal products without further processing. In these states certain activities which are an extension of the production of plant and animal products are also considered to be agricultural activity.

In Italy, the concept of agricultural activity has been regulated in the Civil Code. Agricultural activity is understood as the cultivation of land, forestry and animal husbandry. Such activity may be considered to be agricultural if it is directly related to the development of the biological cycle of plants or animals, also if it an essential stage of cycle during which land, forest, fresh water, salt water or sea water is used. In additional, agricultural activity is also is direct activity connected with mixing, storage, processing and selling of products which are produced predominantly as a result of land cultivation, forestry or husbandry. Agricultural activity is also the provision of goods or services by means of the equipment or resources of a farm used in an ordinary manner as well as activity connected with hosting guests ${ }^{33}$.

The correct qualification of activities falling within the scope of the agricultural activity definition is important in as much as it causes lower tax burden. This a result of the manner of determining the tax basis and therefore adopting either the simplified method or the real method which consists in maintaining tax documentation ${ }^{34}$.

It should emphasised that most Italian farmers use the simplified method, which is more beneficial because of lower fiscal burden. Profits related to direct activity involving mixing, storage, processing and sales of agricultural and husbandry products may, under Italian tax law, be considered as profits from agricultural activity if the object of such activity are products obtained predominantly from land cultivation, forestry or

32 S. Deeks, Trading Income, [in:] Revenue Law: Principles and Practice, ed. Natalie Lee, Croydon 2013, pp. 325-326.

${ }^{33}$ Article 2135 ( 2 R.D). 16 marzo 1942, n. 262, Approvizazione del testo del Codice civile, hereinfter referred to the Italian Civil Code.

${ }^{34}$ Silvia Pansieri, I redditi fondiari, [in:] Manuale di diritto tributario, ed. G. Falsitta, Padova 2016, p. 162 ff. 
husbandry and if such activity was listed in an ordinance issued by the Minister of Finance ${ }^{35}$.

Income from the activities mentioned above, other than the income enumerated in the ordinance of 2015 are deemed to be income connected with conducting ordinary economic activity ${ }^{36}$. It should emphasised that income from agricultural activity consisting in the production of plant and animal products without further processing is, as a general rule, determined on the basis of the so-called cadastral value of land ${ }^{37}$. In the case of activity consisting in mixing, storage, processing and selling of agricultural and husbandry products, whenever such activity was included in the ordinance of 2015, income is fixed by levying the profitability coefficient of $15 \%$ on the amount calculated by adding the registered transactions or the transaction subject to VAT ${ }^{38}$.

In France, the taxation of the sales of processed agricultural products is somewhat different. French legal and tax regulation in certain circumstances allow both the sales of agricultural products produced within one's own farm and processing of such products. Following the stance developed by the doctrine and the French tax administration, agricultural activity includes activities which consists in inter alia the sales of milk product from one's own animal farm if such sales are conducted from specially

${ }^{35}$ See D.M. 13 febbraio 2015, Individuazione dei beni che possono essere oggetto delle attivita' agricole <connesse>, di cui all'art. 32 del testo unico delle imposte sui redditi, hereinafter referred to as the Ordinace of 2015.

According to this Ordinance the following were considered to be the subject od agricultural economic activity. The production of: bread; fresh and dry pasta; wine; grappa; vinegar; cider and other fruit wines; malt, beer and herb extracts; meat products. Slaughtering and producing dried meat products, salted or smoked. And also the production of smoked meats and salami; processing and preserving potatoes, producing potato chips and peeling industrial potatoes; producing fruit and vegetable juice; the production of olive oil and oil form oilseeds; the production of corn oil; the production of milk products; the production of cereal products and flour or meal from dried leguminous vegetables, roots or tubers or edible nuts; processing, rafination and packaging of honey; the production of fruit syrups; filleting fish and preserving fish, and also preserving molluscs or crustaceans by freezing, drying, smoking, salting and placing them in preserves.

${ }^{36}$ See more: Nicola D’Amati, Redditi fondiari (diritto tributario), [in:] Enciclopedia Giuridica Treccani.

${ }^{37}$ See more: Francesco Teasuro, Istituzioni di diritto tributario, Milano 2016, p. 37 ff.

${ }^{38}$ See article 56 bis (2) of the Act of 1986. 
adjusted vans; gardeners selling plant products to consumers from dedicated permanent installations; the sales of plant products conducted by nurserymen, also when it takes place in a shop or by means of catalogue sales ${ }^{39}$.

It should be therefore pointed out that agricultural activity is such sales of own agricultural products during which farmers perform activities similar to trade activity, i.e. activities such as using a company name, a trademark, dedicated installations or engaging additional staff. In the case of the sales of processed agricultural products, the literature ${ }^{40}$ emphasises that revenue generated from such activity is not considered to be revenue from industrial or trade activity.

However, in this case one should pay attention to the degree to which a given product was processed and also to very nature of the product which was obtained as a result of processing. If the end product loses the features of an agricultural product (e.g. wood transformed into furniture), the revenue from its sales may nor, for obvious reasons, be qualified as resulting from agricultural activity. Revenue is thereby considered revenue from agricultural activity if it results from the natural extension of an act of agricultural production. The doctrine emphasises that such revenue includes revenue from the production charcoal; the production and distillation of wine; milling and packaging aromatic plants ${ }^{41}$.

In addition, in order to qualify certain activities into agricultural activity, these activities must be strictly subordinated to widely understood activities related to the nutrition of humans and animals. This means that revenue from agricultural activity shall be amounts obtained from the sales of products produced as a result of activities such as: distillation of beets or grape seeds, the production of flour, own or commissioned laughter of animals, producing offal originating from own poultry production or making products on the basis of honey obtained from own apiaries.

\footnotetext{
${ }^{39}$ Michel-Pierre Madignier, Fiscalité agricole et viticole approfondie, Paris 2008, p. 17.

${ }^{40}$ Ibidem, p. 18.

${ }^{41}$ Ibidem, p. 19.
} 


\section{CONCLUSIONS}

It is not possible to provide an unambiguous assessment of the regulations, in force since 1 January, concerning the taxation of income from the sales of processed agricultural products. On the hand, one should respond positively to an attempt to regulate the issue, significant from the point of view of entities conducting economic activity, of the taxation of the sales of processed agricultural products. It should be emphasised that for many years the Polish legislature did not seem to notice this issue and the changes introduced by the amendment in 2015 should undoubtedly contribute to improving the conditions for conducting activity by some farmers, e.g. those who run agro-tourist farms. In the other, the regulations themselves should be critically assessed.

What is controversial are the criteria which must be met so that income generated by a farmer from the sales of processed agricultural products is not qualified as income from non-agricultural economic activity. The first of these criteria is a duty to sell the products only to consumers. It seems the statutory prohibition on the sales of the products to legal persons, organisational units without legal personality or to natural persons for the purposes of their non-agricultural activity significantly limits the availability of these products on the market. The result of including this condition in Personal Income Tax Act is that many farmers will not undertake activities connected with processing agricultural products because they will find it extremely difficult to sell them. One of the basic problems encountered by people processing agricultural products is finding a market for them. This requires investing time and money which they may lack for different reasons. One should also remember processing agricultural product is only a secondary activity of a farmer allowing him or her to generate additional income, so important from the perspective of the phenomenon of fluctuations in prices of agricultural products on the market. It should be noted that in Poland there is a number of entities conducting economic activities which specialise in the sales of regional and organic products. When products processed by farmers in a non-industrial way may not be directly delivered to such entities, farmers do nor generate additional income and consumers do not receive food that would be competitive in terms of price and quality. 
What is also an unfortunate solution is the condition that processing of plant and animal products and their sales may not involve employment based employment contracts, mandate contracts, contracts for specific work and similar contracts. Such restriction may be justifies by the fact that the preference in question is aimed at farmers who produce and sell their products on their own or with a help of members their family or household. However, one might argue that the lack of this regulation might lead to a slight increase of employment in rural areas and partial legalisation of income from work consisting in a help with the production and sales of processed agricultural products.

There are also many doubts as to the condition concerning the places where processed products may be sold. Firstly, farmers may only conduct sales only at the place where given products were produced, i.e. usually on farms. It is therefore easy to notice that a much better situation of farmers who have farms either close to cities or close to places which are particularly attractive in terms landscape or climate, those that can attract a considerable number of tourists. Otherwise, the sales of processed products will not be possible because of a very small number of potential clients.

Secondly, farmers may conduct sales in markets, understood as any places intended for trade. One should however remember that sales in buildings or their parts shall not in this case constitute sales in a market. This means that the sales of processed agricultural products in market halls and at places not designated for trade shall result in the revenue being qualified as revenue from non-agricultural economic activity.

The limitation mentioned above should be very critically assessed as the legislature does not attempt to meet the social expectations. At present, markets selling health food enjoy a great popularity in Polish towns and cities. They are usually organized in indoor spaces where farmers sell not only unprocessed plant and animal products but also products processed by them, such as cream, butter and cheese. One should also remember that many Polish towns and cities are currently trying to civilise the so-called green markets, where agree-food is sold, by moving them specially built halls. As a result, in the light of currently binding regulations of tax law, revenue generated by a farmer from the sales of processed products in the cases described above should be qualified as revenue from non-agricultural economic activity. 
When assessing the currently binding regulations concerning the taxation of revenue from the sales of unprocessed agricultural products, one cannot help feeling that the situation of Polish farmers somewhat resembles the situation of convicts on a desert island, who one day freed and told that they can go anywhere they want. Polish farmers who intend to sell unprocessed agricultural products are in a similar situation. Although the Polish legislature has introduced, under tax lax, legal regulations which shall allow such sales to be subject to preferential tax treatment and farmers shall be discharged form a part of instrumental duties, all this has been subject such restrictions that in practice the situation of Polish farmers has not considerably improved.

It seems therefore that the regulations introducing the conditions discussed above should be changed. Although the legislature aimed to avoid preferential tax treatment for non-industrial processing of agricultural by large entities resembling companies rather than family farms, the instruments selected for this purpose do not seem right. Perhaps a better method would be to introduce an amount limit (for example PLN 50000 or 100 000) up to which one might generate revenue subject to preferential tax treatment and therefore not qualify them as revenue from non -agricultural economic activity.

In the future, if the Polish legislature decided to subject revenue from agricultural activity to income tax, it would be worth considering whether processing of one's own agricultural products produced in a non-industrial manner should perhaps be qualified as a natural extension of agricultural activity. As a result such activities would defined as agricultural activity which should, at least in the case of small and medium farms, be subject to tax treatment that would preferential in comparison to non-agricultural economic activity.

\section{REFERENCES:}

A study conducted by the Public Opinion Research Centre show in recent years are increasingly interested in all types of different diets; there are also more people who choose products marked as healthy and ecological when they do their shopping. See: Diety Polaków. Komunikat z badań CBOS, 
No. 113/2014, Warszawa, August 2014, http://www.cbos.pl/SPISKOM. POL/2014/K_113_14.PDF;

D’Amati, Nicola, Redditi fondiari (diritto tributario), [in:] Enciclopedia Giuridica Treccani;

Borowska A., Wsparcie instytucjonalne sprzedaży bezpośredniej produktów rolnych $w$ Polsce $w$ latach 2007-2013 na przyktadzie targowisk, „Marketing i Rynek” 2015, no. 8, pp. 61-69;

Deeks S., Trading Income, [in:] Revenue Law: Principles and Practice, ed. Natalie Lee, Croydon 2013, pp. 325-326;

Kapała A., J. Kalinowski, S. Minta, Sprzedaż bezpośrednia w Polsce na przyktadzie produktów pochodzenia zwierzęcego, Stowarzyszenie Ekonomistów Rolnictwa i Agrobiznesu. Roczniki Naukowe, vol. XVII (4), pp. 116-121;

Leicester, Andrew, Frank Windmeijer, The 'Fat Tax': Economic incentives to reduce obesity, „The Institute for Fiscal Studies. Briefing Note” 2004, no. 49, pp. 1-20;

Madden, David, The poverty effects of a "Fat-Tax" in Ireland, Working Paper Series, UCD, Centre for Economic Research, No 13/03, http://hdl.handle. net/10419/72195 [retrieved: 20 March 2016];

Madignier, Michel-Pierre, Fiscalité agricole et viticole approfondie, Paris 2008, p. 17;

Mytton, Oliver, Alastair Gray, Mike Rayer, Harry Rutter, Could targeted food taxes improve health?, "Journal of Epidemiology and Community Health” 2007, vol. 61, pp. 689-694;

Pansieri, Silvia, I redditi fondiari, [in:] Manuale di diritto tributario, ed. G. Falsitta, Padova 2016, p. $162 \mathrm{ff}$;

Sieczko, A. Sprzedaż bezpośrednia produktów żywnościowych z gospodarstw rolnych, Stowarzyszenie Ekonomistów Rolnictwa i Agrobiznesu. Roczniki Naukowe, vol. XVII (5), pp. 248-250;

Strnad, James Frank, Conceptualizing the "fat tax": the role of food taxes in developed economies, "Southern California Law Review" 2005, vol. 78, pp. 1224-1322;

Teasuro, Francesco, Istituzioni di diritto tributario, Milano 2016, p. $37 \mathrm{ff}$;

Zachowania żywieniowe Polaków. Komunikat z badań CBOS, No. 115/2014, Warszawa, August 2014, http://www.cbos.pl/SPISKOM.POL/2014/K_115_14.PDF, retrieved on: 17.11.2016. 
